\title{
31. ICE RAFTING, GLACIAL-MARINE SEDIMENTS, AND SILICEOUS OOZES: SOUTH ATLANTIC/SUBANTARCTIC OCEAN ${ }^{1}$
}

\author{
Detlef A. Warnke² and Carl P. Allen ${ }^{2}$
}

\begin{abstract}
In the modern Southern Ocean, very little debris is delivered to the sea by icebergs. Whatever debris may be present beneath the ice sheets is lost near the grounding line. Whatever till is present beneath ice streams is also lost near the grounding line, but it may significantly contribute to fine-sized suspensoids. The bulk of the ice-rafted debris encountered at Ocean Drilling Program Leg 114 drill sites was delivered in the geologic past, when antarctic glaciers had greater erosive power (Warnke, 1970). Whatever ice-rafted detritus is present is essentially only an admixture to rapidly accumulating siliceous oozes. These oozes present a paradox because, in general, primary production in the open Southern Ocean is quite low. However, because the preservation of antarctic diatoms is far better than their preservation in low latitudes, high sedimentation rates result. These relationships are explained either in terms of high flux rates during the growth season, or as the result of a "stressed ecosystem," given to significant fluctuations, or as a combination of both mechanisms. These relationships lead to uncertainties in the computation of apparent mass-accumulation rates (AMARs) of ice-rafted detritus (details presented by Allen and Warnke, this volume). Nevertheless, a clear picture of the changes in antarctic glaciation emerges, particularly when viewed in the light of investigative results by Froelich et al. (this volume) and Hodell et al. (this volume).

The most significant results of our investigations of ice-rafted detritus are the recognition of (1) the antiquity (about 23.5 Ma) of (albeit insignificant) ice rafting to these latitudes and (2) a period of increased ice-rafting activity and northward expansion of the zone of major iceberg melting, which is perhaps the marine equivalent of the deposition of Sirius till (Sirius till equivalent, marine = STEM), but only if the suggested Pliocene age of these tills can be confirmed. The beginning of delivery of debris to the ocean by these large wet-based ice sheets started about $2.46 \mathrm{Ma}$. The "end of STEM" is within a cluster of AMAR peaks younger than $2 \mathrm{~m} . \mathrm{y}$. Based on the strength of the detailed opal curve presented by Froelich et al. (this volume) as well as the oxygen and carbon isotope curves presented by Hodell et al. (this volume), we place this significant event in antarctic glacial history at about $1.77 \mathrm{Ma}$. This event signals the beginning of more modern antarctic conditions (with polar ice sheets and reduced efficiency to erode). Hole $704 \mathrm{~A}$ shows a cluster of peaks at about $0.7 \mathrm{Ma}$ that may signal a last return to wet-based glaciers. Later peaks are correlative (in part) with the "classical" Northern Hemisphere glaciations. Peaks at 3.11 Ma and older signify smaller ice-rafting episodes and are discussed by Allen and Warnke (this volume).
\end{abstract}

\section{INTRODUCTION}

Antarctica has experienced a long history of glaciation, spanning tens of millions of years. This long history, once advocated mainly by paleoceanographers studying oxygen isotopes (see Miller et al., 1987; Wise et al., 1985; Matthews and Poore, 1980) and land-based geologists (e.g., LeMasurier and Rex, 1982; Birkenmajer, 1986), has now been confirmed by drilling in Prydz Bay (Kennett et al., 1988), reconfirming results from earlier drilling efforts in the Ross Sea (Hayes and Frakes, 1975; Leckie and Webb, 1983). Had continental Antarctica been of greater extent, and had it drifted across the South Pole as its Paleozoic ancestor did, a trail of sediment accumulations and geomorphic features might have been left for us to study. In Antarctica, however, no such large-scale shift occurred because the continent has been quasi-stationary since the Mesozoic.

The isotope record (see Miller et al., 1987) suggests that glacial pulses have followed each other since the Eocene, superimposed on a trend of accelerating climatic deterioration. During this history the centers of ice accumulation must have shifted from mountain ranges to high plateaus. Finally, the ice carapace covered East Antarctica and the West

${ }^{1}$ Ciesielski, P. F., Kristoffersen, Y., et al., 1991. Proc. ODP, Sci. Results, 114: College Station, TX (Ocean Drilling Program).

2 Department of Geological Sciences, California State University, Hayward, CA 94542 (Allen, present address: Engineering-Science Inc., 600 Bancroft Way, Berkeley, CA 94710).
Antarctic Archipelago and joined these fragments into a "quasi continent" by means of marine-based ice sheets. Most of the record of this remarkable history, however, is inaccessible, buried beneath the present-day ice cover. Only the Transantarctic Mountains, the Dry Valleys, and continentalmargin drill sites afford direct evidence. Once the glaciers had reached sea level, calving ensued and ice rafting began, at first close to the continent and in then-existing inland seaways. Once a Polar Front Zone had developed (Ciesielski and Weaver, 1983), what basal sediment remained in the bergs was largely dropped in that zone of major melting (Anderson, 1985). Analysis of ice-rafted debris in cores from the Southern Ocean permits delineation of the history of ice rafting and allows conclusions concerning the glacial history of the source areas. However, the interpretation of percentages of icerafted debris or even apparent mass-accumulation rates (AMARs) is not straightforward.

The present-day glaciation of Antarctica is by no means an analog of Neogene Northern Hemisphere glaciations, nor is it an analog of earlier phases of antarctic glaciation. It may indeed be unique. Whether or not it had a counterpart in the Paleozoic or Precambrian glacial episodes remains to be determined. Any interpretation of the ice-rafted debris record must take into account the boundary condition on the continent(s) and the other variables that determine the flux of debris to the marine environments (see Warnke, 1970). In addition, the flux rates of bulk sediment to the seafloor must be carefully evaluated because they determine sedimentation rates, which in turn critically influence the AMARs used in 
our interpretations. Our understanding of these processes and variables is far from complete. Nevertheless, progress made in the last two decades or so permits a far better understanding of the sedimentary record than was previously possible.

\section{Present Setting}

Before analyzing the glacial-marine record of Ocean Drilling Program (ODP) Leg 114 drill sites, a review of present-day antarctic environmental settings is in order.

\section{Southern Ocean Glacial-Marine Sedimentation}

Anderson et al. (1983) distinguished three groups of glacialmarine sediments of the antarctic continental shelf. The first group, "transitional glacial-marine sediments," consists mostly of diamicts that may exhibit subtle stratification. Anderson et al. (1983) thought that these sediments were derived from basal debris zones and were deposited only beneath an ice shelf. These deposits resemble lodgement tills; deposition in a marine setting is indicated by low-diversity benthic foraminifer assemblages.

A second group of glacial-marine deposits occurs in shallow parts of the continental shelf and on the shelf break-upper slope. Termed "residual glacial-marine sediments," they consist largely of gravel and sand and minor silt and clay, all of which were produced from melting icebergs. Most of the original content of fines was removed by currents. These sediments typically contain a significant carbonate fraction, mainly derived from benthic organisms.

A third group consists of muds and diatomaceous muds with generally $<10 \%$ ice-rafted debris. These "compound glacial-marine sediments" consist of mixtures of terrigenous and marine components and are the most widespread glacialmarine sediments on the antarctic seafloor today. They contain a large biosiliceous component and, in some areas, only minor terrigenous admixtures, even close to the ice edge. This fact indicates that the supply of terrigenous sediment is presently restricted.

Anderson et al. (1983) allocated these sediment types to different polar glacial-marine facies: namely, the compound glacial-marine sediments to the "iceberg glacial-marine facies" deposited in front of the calving wall of ice shelves and in front of ice walls, and the transitional glacial-marine sediments next to the grounding line beneath ice shelves to the "ice shelf glacial-marine facies." Lodgement till occurs beneath the grounded ice sheet, and sand and gravel constitute the "ice wall facies." Mass-flow processes and turbidity currents are important on the deeply, glacially eroded shelf floor. The importance of mass-flow processes on the antarcticshelf seafloor has recently been questioned by Barnes and Lien (1988), who noted ice-bed turbates in water depths up to $500 \mathrm{~m}$, albeit in a limited area. They proposed that these turbates formed unstructured marine diamictites "difficult to distinguish from glacial-marine deposits such as those reported by Anderson et al. (1983)." The reader is referred to the original publications for further reference. An extensive review of terminology was provided by Kellogg and Kellogg (1988), who unfortunately further burdened the nomenclature by introducing the term "cryogenic sediments."

The present-day antarctic glacial setting is dominated by calving as the main process of ablation. It lacks meltwater and meltwater plumes (Anderson et al., 1983) and produces icebergs that are virtually free of conspicuous debris of any kind (Warnke, 1970; Odell, 1952), exceptions notwithstanding (Warnke and Richter, 1970; Anderson et al., 1980). Indeed, "we have steamed along and flown over hundreds of miles of the ice margin looking for sediment-laden glaciers, ice walls, and icebergs," but "those observed sediment-laden glaciers and icebergs averaged $<1 \%$ of all those observed" (Anderson et al., 1983). It is implied in the model of Anderson et al. (1983; see their fig. 14) that basal debris is carried in marine ice sheets and is deposited as lodgement till or transitional glacialmarine sediments. Whether or not such deposition is going on at the present time still has to be determined. However, antarctic ice streams may well represent "conveyor belts", that even at the present time deliver erosional debris to the ocean. Ice streams have recently received increased attention (reviewed by Bentley, 1987) because of uncertainties surrounding the stability of marine-based ice sheets and ice shelves.

It has been suggested that ice stream B, one of the major suppliers of ice to the Ross Ice Shelf, is underlain by a saturated porous layer (Blankenship et al., 1986) and that this layer is glacial till (Alley et al., 1986). The thickness of this basal till is 5 or $6 \mathrm{~m}$. It is not lodged, and indeed, deformation within the till is the primary mechanism by which the ice stream moves (Alley et al., 1986). The till is produced by steady-state erosion of $\sim 0.5 \mathrm{~mm} / \mathrm{yr}$ of rock in the catchment area and the upstream part of the ice stream. However, the material is deposited in morainal banks or "till deltas" at the grounding line (Alley et al., 1986). Therefore, this material generally is not available for incorporation into icebergs and for long-distance transport. One may surmise, however, that the morainal banks and/or till deltas are points of origin for the mass-wasting processes proposed by Anderson et al. (1983), and that they are sources for fine-grained suspensoids delivered to the Southern Ocean.

In any event, antarctic glaciers, even in the comparatively mild climate of the Antarctic Peninsula (wet-based glaciers), do not contain much, if any, basal debris (Warnke, 1968, 1970). This statement is based on several months of field observations. The interested reader is referred to the original publications. We hasten to add that terms like "wet-based" and "dry-based" are used for convenience only, until a better consensus develops among glacial geologists. At the present time, and for whatever reason, the vast majority of either small bergs calving from individual glaciers or large tabular icebergs calving from ice shelves is free of observable debris. There are, of course, exceptions (see Warnke and Richter, 1970). For a review of observations of icebergs carrying debris, refer to Anderson et al. (1980). The paucity of antarctic debris-carrying icebergs is in contrast to certain Northern Hemisphere glaciers (e.g., the subarctic glaciers draining into Glacier Bay), which may be laden with debris (Ovenshine, 1970).

All Leg 114 drill sites analyzed by us (Hole 699A, Site 701, and Hole 704A; see Fig. 1) contained varying amounts of ice-rafted debris; however, because of the preceding observations, ice-rafted debris as indicator of paleoclimates has to be used with caution (Warnke, 1970; Anderson et al., 1980), at least in the Southern Ocean. Of the different sediment types described by Anderson et al. (1983), only compound glacialmarine sediments are similar to those encountered at our drill sites. Whether these sediments are also part of the iceberg glacial-marine facies proposed by Anderson et al. (1983) is debatable. Because the classification established by Anderson et al. (1983) is intended for the antarctic continental margin, the extension of this classification to our drill sites is perhaps not warranted.

On the other hand, Molnia (1983) used the term "icerafted," or "distal facies," for the glacial-marine facies he investigated in the North Atlantic. The sediments consist of ice-rafted and biogenic (mainly calcareous) components in various proportions. The fundamental difference between the sediments investigated by Molnia (1983) and the sediments 


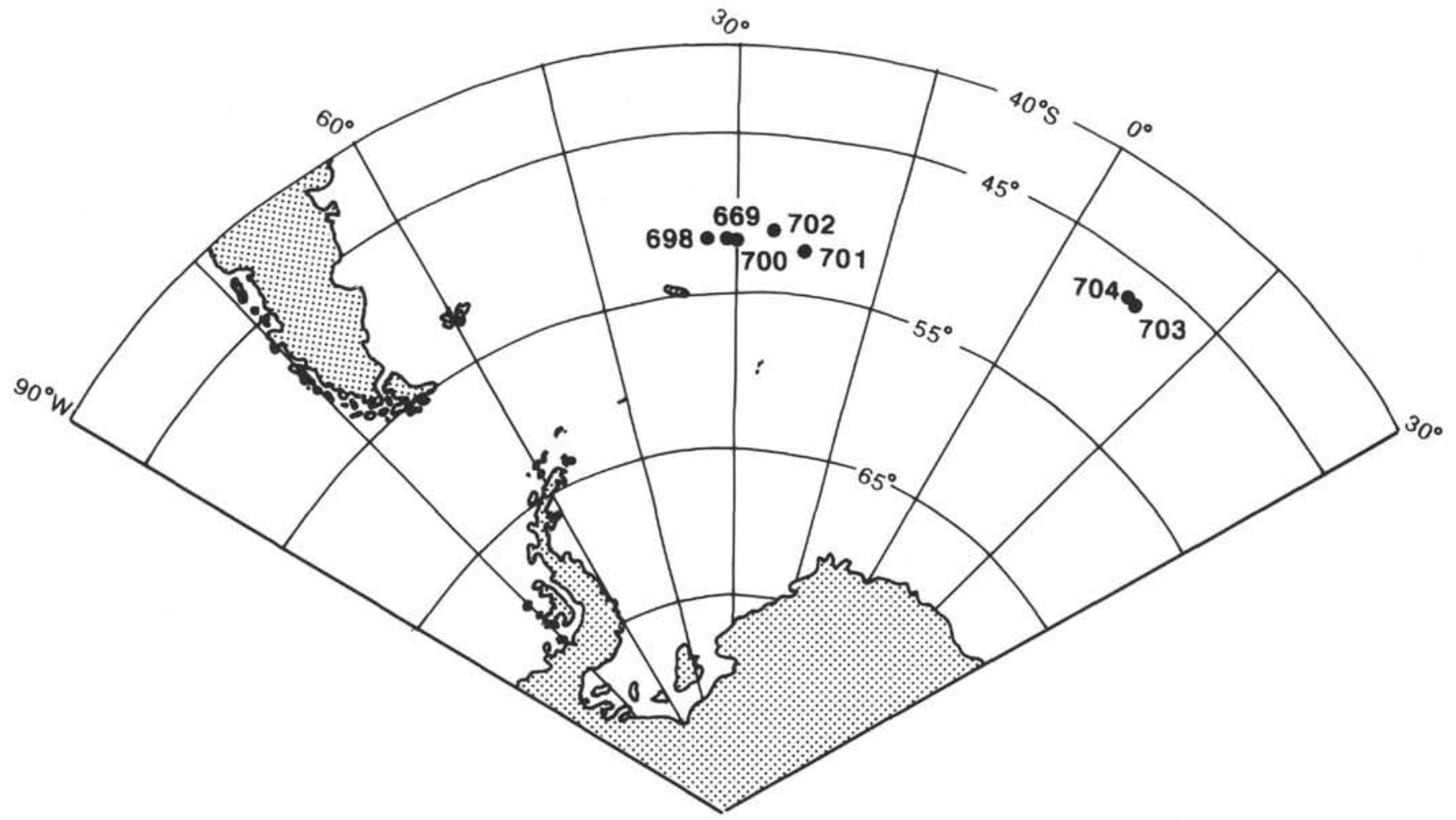

Figure 1. Leg 114 drill sites.

under study here is the far greater percentage of terrigenous components in North Atlantic sediments deposited during glaciations. At the studied Leg 114 drill sites, such types of sediments are invariably lag deposits and are therefore excluded from further study.

\section{Southern Ocean Biosiliceous Productivity and Sedimentation}

The sediments from Sites 699 and 701 investigated by us are essentially siliceous muds and oozes with admixtures of ice-rafted debris and calcareous biogenic components. They resulted from high rates of biosiliceous accumulation, which, however, present a paradox, as outlined in the following.

At the present time, the seafloor of the northern part of the Southern Ocean, including the Polar Front Zone, consists of biosiliceous (essentially diatomaceous) oozes. This has been interpreted by numerous writers to reflect high productivity rates in the Southern Ocean (and not just the lack of dilution by terrigenous fines). Indeed, the assumption of high rates of primary productivity leading to the "proverbial" richness of the Southern Ocean is perhaps the most enduring myth of oceanographic folklore. Geologists and biologists alike have contributed to the genesis of this myth; geologists by assuming a priori a linear relationship between "primary productivity" and "biosiliceous sedimentation," and biologists perhaps by using observations from bloom conditions to extrapolate generalizations for the entire Southern Ocean. Once this erroneous assumption had appeared in the literature, it was slow to be corrected in the biologic literature (for a review, see El-Sayed, 1987), but it remained firmly entrenched in the geologic literature. Only one of the various models proposed for Southern Ocean sedimentation (Tucholke et al., 1976) even considers the possibility of low rates of primary production in the Southern Ocean.

What are the rates of present-day phytoplankton productivity in the Southern Ocean, and what are the factors gov- erning primary production? It should be emphasized that our data base for quantitative information is still sparse, despite decades of research, and that all conclusions are tentative (but no longer speculative). El-Sayed (1987) stated that in the Southern Ocean, "the open-ocean system has rates of production typical of oligotrophic regions (i.e., $0.1 \mathrm{gC} \mathrm{m}^{-2} \mathrm{day}^{-1}$ ) and the inshore waters register rates $>5 \mathrm{gC} \mathrm{m}^{-2} \mathrm{day}^{-1}$, which are comparable to upwelling systems." The results of investigations carried out in the 1960 s and 1970 s further revealed that productivity in Southern Ocean open water varies by at least 1 or 2 orders of magnitude and that, in general, antarctic waters are productive mainly in coastal regions (El-Sayed and Turner, 1977). Even the last statement (concerning coastal water productivity) should only be used with extreme caution. Warnke et al. (1973) investigated oceanographic parameters in the Arthur Harbor area (Antarctic Peninsula) and concluded that primary productivity at the time and place of investigation was low, corroborating earlier results from Bransfield Strait.

What emerges is the great spatial and temporal variability in phytoplankton biomass and primary productivity (El-Sayed and Weber, 1982). Overall, however, a comparison of the Gulf of Mexico/Caribbean Sea with the antarctic/subantarctic showed that the average value for the Gulf/Caribbean was about double the average value for the southern waters (i.e., 0.289 vs. $0.134 \mathrm{gC} / \mathrm{m}^{2} / \mathrm{day}$; see El-Sayed and Turner, 1977), which is not really surprising in view of earlier observations by Walsh (1969).

El-Sayed (1987) discussed the parameters that govern phytoplankton productivity in antarctic waters. Light is the factor governing the changes in phytoplankton biomass and primary production. During the austral summer, a tremendous amount of radiant energy is received at the surface. However, Sakshaug and Holm-Hansen (1986) pointed out that the photochemical apparatus of antarctic phytoplankton is saturated between 100 and $180 \mu \mathrm{E} / \mathrm{m}^{2} / \mathrm{s}$ (Fig. 2) depending on water 


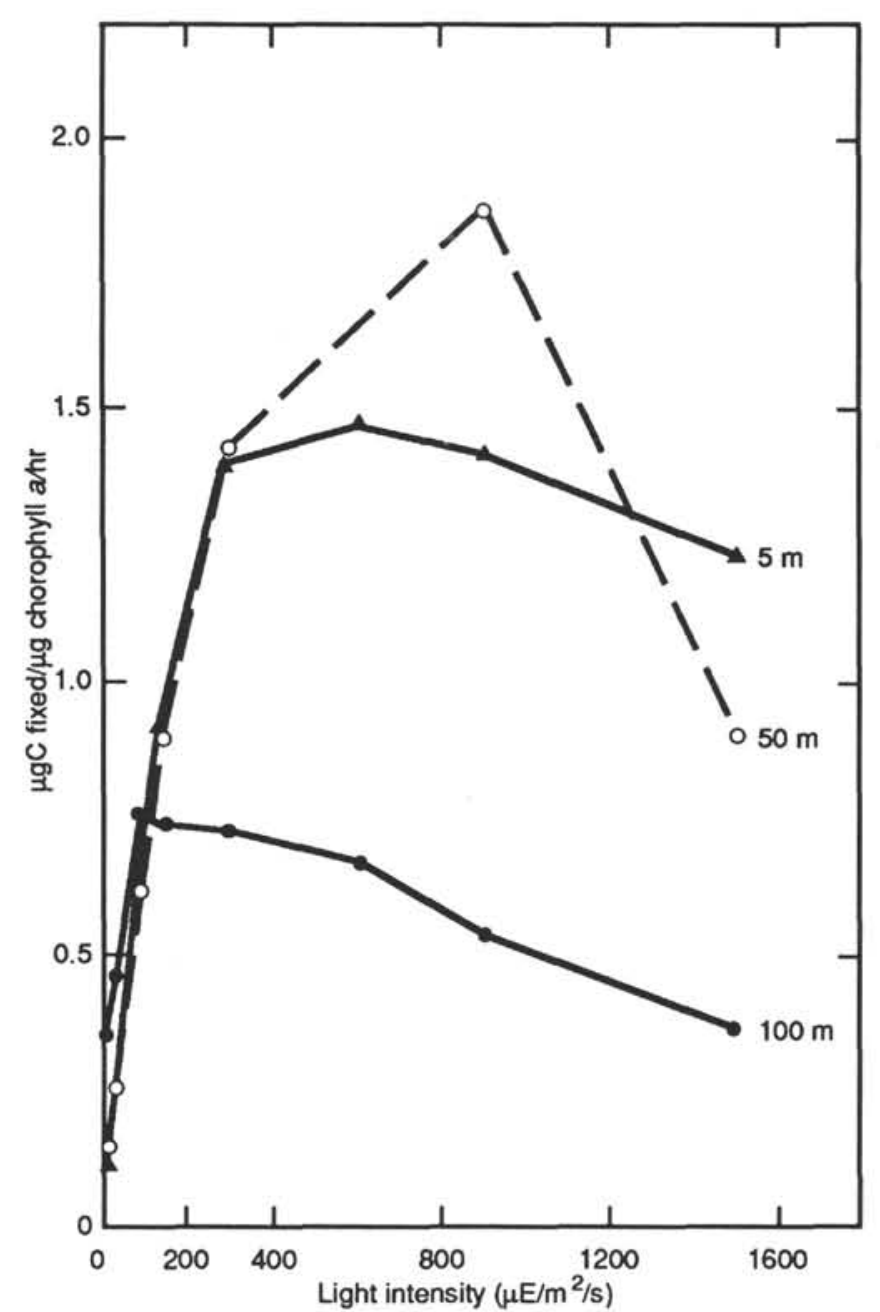

Figure 2. Photosynthesis of antarctic phytoplankton plotted vs. light intensity. Antarctic phytoplankton is "saturated" between 100 and $180 \mu \mathrm{E} / \mathrm{m}^{2} / \mathrm{s}$, depending on the depth from which the sample was obtained (after Sakshaug and Holm-Hansen, 1986).

depth. The incident light flux on clear days is about 1500 $\mu \mathrm{E} / \mathrm{m}^{2} / \mathrm{s}$. Therefore, phytoplankton in surface waters will either be saturated by light flux or photoinhibited. These figures point to low photosynthetic efficiency of antarctic phytoplankton.

Temperature as a factor in determining primary productivity has been the subject of debate for years. El-Sayed (1987) maintains that temperature can be a rate-controlling factor in the upper $10-20 \mathrm{~m}$ of the water column. Specific growth rates $(\mu)$ for antarctic phytoplankton are, for instance, 0.1 to 0.3 doublings per day in the Ross Sea (Holm-Hansen et al., 1977) and as high as $\mathbf{0 . 7}$ doublings in the Weddell Sea (as recorded by El-Sayed and Taguchi, 1981). As pointed out by El-Sayed (1987), even this high value is still far less than that predicted by Arrhenius's law applied to phytoplankton growth. It seems, therefore, that the very low temperatures in the antarctic do indeed limit algal growth rates, a conclusion supported by the experimental work of Tilzer et al. (1986).

It is now accepted that nutrient levels are not limiting factors in antarctic phytoplankton productivity, not in nearshore waters (e.g., Warnke et al., 1973) nor in the open ocean, not at the peak of the growth season nor even during plankton blooms (El-Sayed, 1971). Perhaps silica may be the most limiting nutrient factor, as indicated by silica-distribution patterns (Allanson et al., 1981).

Water-column stability must surely be a factor in productivity, as reviewed by El-Sayed (1987). Near-ice edge blooms can perhaps be explained in terms of a shallow pycnocline produced by meltwater (see Sakshaug and Holm-Hansen, 1986). On the other hand, the Antarctic Polar Front has been described by some workers as containing low phytoplankton crops (caused by low water-column stability), whereas others found higher than average chlorophyll $a$ and primary-production values (El-Sayed and Weber, 1982). Yamaguchi and Shibata (1982) recorded high chlorophyll $a$ values on the southbound leg of their voyage, and low values on the northbound leg. The matter remains unresolved, but higher standing-crop values (and eventual incorporation into the sediment?) compared with the remainder of the Southern Ocean seem possible.

The question of grazing pressure exerted by euphausiids is currently being investigated. In general, numbers of krill seem to be inversely correlated with phytoplankton biomass. It is interesting to speculate about the "sedimentary" consequences of a phytoplankton bloom (perhaps late in the growing season?) with insufficient time for herbivore-population growth. Even low rates of "diatom productivity," if not accompanied by excessive grazing pressure, would lead to accumulation of siliceous oozes if dissolution is low compared with that of low latitudes.

Given the overall low average annual primary productivity of the present-day Southern Ocean, the complexity of the patchiness and variability of biologic processes and populations, it is clear that interpretations of the sedimentary record in terms of "paleoproductivity" are not straightforward, at least not in the Southern Ocean.

Direct measurements of paleoproductivity are, of course, not possible. Proxy indicators have to be used and, as can be expected, are fraught with uncertainties. Indeed, quantitative determination of rates of paleoproductivity is one of the most difficult tasks of paleoceanography (Hay, 1988). Nevertheless, such determinations have been carried out, based on sets of empirical correlations of particulate organic-carbon flux data with data sets of modern, average annual productivity and the organic carbon content of surface sediments. The appropriate equations are developed by Stein (1986) and Stein et al. (1986), in part based on determinations by Bralower and Thierstein (1984). The reader is referred to Stein (1986). Of course, such quantitative paleoproductivity indexes have large uncertainties, as reviewed by Emerson and Hedges (1988), but these indexes are all we have. A few preliminary determinations for our drill sites, using Stein's (1986) equations, show that productivity in the last few million years was quite low, even at Site 704 (despite high sedimentation rates), on the order of a few tens of $\mathrm{gC} / \mathrm{m}^{2} / \mathrm{yr}$ at best (and even making the generous assumption that all organic carbon is marine derived). There are, however, fluctuations. Correlation of these fluctuations with floral/faunal composition and with flux rates of opal and ice-rafted debris has yet to be accomplished.

\section{ORIGIN OF SOUTHERN OCEAN SILICEOUS OOZES}

In view of the preceding considerations the origin of siliceous oozes in the Southern Ocean is not simply explained in terms of productivity. The question of origin of these oozes has been addressed by a number of workers, starting with Philippi (1912) and Schott (1939), and continuing with Goodell and Watkins (1968), Brewster (1980), and Cooke and Hays (1982), among others. These workers defined the limits and the nature of the siliceous oozes and related their occurrence 
to various environmental parameters. Burckle and Cirilli (1987) specifically related the occurrence of Southern Ocean diatomaceous oozes to surface-water "biosiliceous" productivity, and Shemesh et al. (in press) addressed the problem of antarctic diatom dissolution and its effect on the final floral assemblage (thanatocoenosis) in antarctic sediments.

At the present time, the Southern Ocean is the primary silica sink in the world's oceans. This is underscored by the budget calculations of DeMaster (1981). It appears that, based on the removal rubric within his marine-silica budget, about $78 \%$ of all silica removed in the world's ocean is removed in the antarctic deep sea. Additional removal is accomplished in depressions on the antarctic continental shelf (Ledford-Hoffman et al., 1986). The change with geologic time to increasing biogenic opal-accumulation rates in the Southern Ocean has been documented, among others, by Brewster (1980). Anderson (1985) showed peaks of opal-accumulation rates in the Gilbert Chron, based on limited piston core coverage.

The factors that govern the extent of diatom productivity in the Southern Ocean are temperature (northern boundary) and sea-ice cover (southern boundary). The northern boundary of high rates of productivity is about $8^{\circ} \mathrm{C}$. This figure is based on observations by Burckle et al. (1987) and Fenner et al. (1976), among others, and on experimental work by a number of investigators, reviewed by Burckle and Cirilli (1987). In the Pacific sector of the Southern Ocean, this boundary seems to coincide with the Subantarctic Front. Other investigators determined slightly higher temperatures for the sharp drop in photosynthetic rates. El-Sayed (1987), for instance, quoted a temperature of $10^{\circ} \mathrm{C}$. In any event, the northern boundary therefore must be in the range of $8^{\circ}$ to $10^{\circ} \mathrm{C}$. These algae grow well at low temperatures, optimally at less than $5^{\circ} \mathrm{C}$, and will not grow well at higher temperatures. The relationships between temperature, diatom productivity, and the northern boundary of the diatom ooze belt seem to be reasonably well established. The southern boundary, however, is less well defined.

Several workers have stressed the importance of sea-ice cover on diatom productivity (reviewed by Burckle and Cirilli, 1987). Cooke and Hays (1982) proposed that the diatom preservation boundary is the northern limit of summer sea ice. This interpretation was challenged by Burckle et al. (1982), who showed that this boundary is well north of present-day summer sea ice. Instead, Burckle and Cirilli (1987) favored the view that this boundary is the northern limit of spring sea ice (averaged). The area south of this boundary will be ice free only during about two summer months, with low diatom productivity averaged annually. Another factor that governs the position of the southern limit of the diatom ooze belt is dilution by lithogenous components. Certainly, this explanation is valid for the geologic past (see Warnke, 1970) and has validity in the present because of the ongoing delivery of at least fine-grained material from parts of the antarctic margin (see the preceding). North of the dilution/sea-ice-cover limit, and south of the $8^{\circ}-10^{\circ} \mathrm{C}$ isotherm, the accumulation of diatomaceous oozes must be related to the far better preservation of antarctic diatom tests, compared with lower latitude organisms. In the central equatorial belt, Hurd (1973) estimated that $90 \%-99 \%$ of surface-water biogenic opal is dissolved before it reaches the seafloor. Additional dissolution occurs within the sediment, leaving a paltry $0.05 \%-0.15 \%$ of the original amount of biogenic opal produced in the euphotic zone. In the Southern Ocean, however, an estimated $50 \%$ is preserved (L. Burckle, pers. comm., 1988). DeMaster et al. (1987) estimated that in Bransfield Strait approximately one-half of the surface-produced silica accumulates in bot- tom sediments (in contrast to carbon accumulation, which is only $10 \%$ of production).

If roughly one-half of surface-water biogenic opal is preserved in Southern Ocean sediment, then primary "siliceous" productivity need not be high to produce high accumulation rates of diatomaceous oozes. Southern Ocean oozes are dominated by Nitzschia kerguelensis, Thalassiosira lentiginosa, and Eucampia antarctica, in that order. Dissolution may change these ratios (Shemesh et al., in press). Burckle and Cirilli (1987), following other authors, attributed the existence of the ooze belt to high "diatom productivity," that is, a large flux of diatom valves to the seafloor during the growth season (the "to-him-who-has-shall-be-given" model): the more diatoms, the better the preservation. Warnke (1970) proposed the "stressed ecosystem" model, in which a stressed ecosystem (because of low temperatures) is given to large fluctuations (refer to reported blooms). If, even occasionally, the secondary producers lag too far behind, a higher flux of noncrushed diatoms, less susceptible to dissolution, would result over time spans of tens or hundreds of years. The sediment trap results of Gersonde and Wefer (1987) lend a measure of support to this contention. The two models are not mutually exclusive. Both models require that diatom species exist that are reasonably resistant to dissolution, and this condition seems to be fulfilled. Just when these resistant species evolved is still uncertain (L. Burckle, pers. comm., 1988). The opal-accumulation rates determined by Brewster (1980) show that this increase in the rate of accumulation started just below the Miocene/Pliocene boundary. This result is in accordance with our findings, for example, at Site 704 (Ciesielski, Kristoffersen, et al., 1988). The complex relationships between "paleo"-floral compositions in the euphotic zone, paleoproductivity, environmental parameters, and dissolution effects have yet to be established.

\section{INTERPRETATION OF RESULTS FROM LEG 114 DRILL SITES: SIRIUS TILL EQUIVALENT, MARINE?}

It is clear from the foregoing discussion that ice-rafted debris data (including AMARs) cannot be explained solely in terms of temperature, but must take into account oceanographic parameters as well as boundary conditions in the source area. In the following discussion, age control is based on information available at the time of writing, but revised in January 1990, when new age models became available. These age models are based largely on paleomagnetic and diatomstratigraphic data (P. F. Ciesielski, pers. comm., 1990). Details of methodology, tables of raw data, and age models are presented in Allen and Warnke (this volume).

The record from Site 699 is rather spotty because of the (as far as time is concerned) large sampling interval (Figs. 3 and 4) and the uncertainties caused by biostratigraphic ambiguities. Ice rafting first occurred about $23.5 \mathrm{Ma}$. We assume that this was accomplished by sporadic bergs that drifted this far north. A modern-type Polar Front probably had not developed yet. Some ice rafting around $8.8 \mathrm{Ma}$ is significant because it corroborates earlier findings from Deep Sea Drilling Project (DSDP) Leg 71 (see Allen and Warnke, this volume, for detailed descriptions of ice-rafting chronology). Additional ice rafting occurred at about $5.9 \mathrm{Ma}$. Development of hiatuses at this site is delineated (Nobes et al., this volume) and discussed elsewhere in this volume. Unfortunately, the entire sedimentary column at Site 699 is probably riddled with hiatuses that cannot be discerned by conventional methods (see Warnke and Pavletich, 1988). Therefore, the high AMARs may reflect "laggy" ice-rafted debris sedimentation rather than Antarctic Polar Front positions. However, we consider the large peaks 


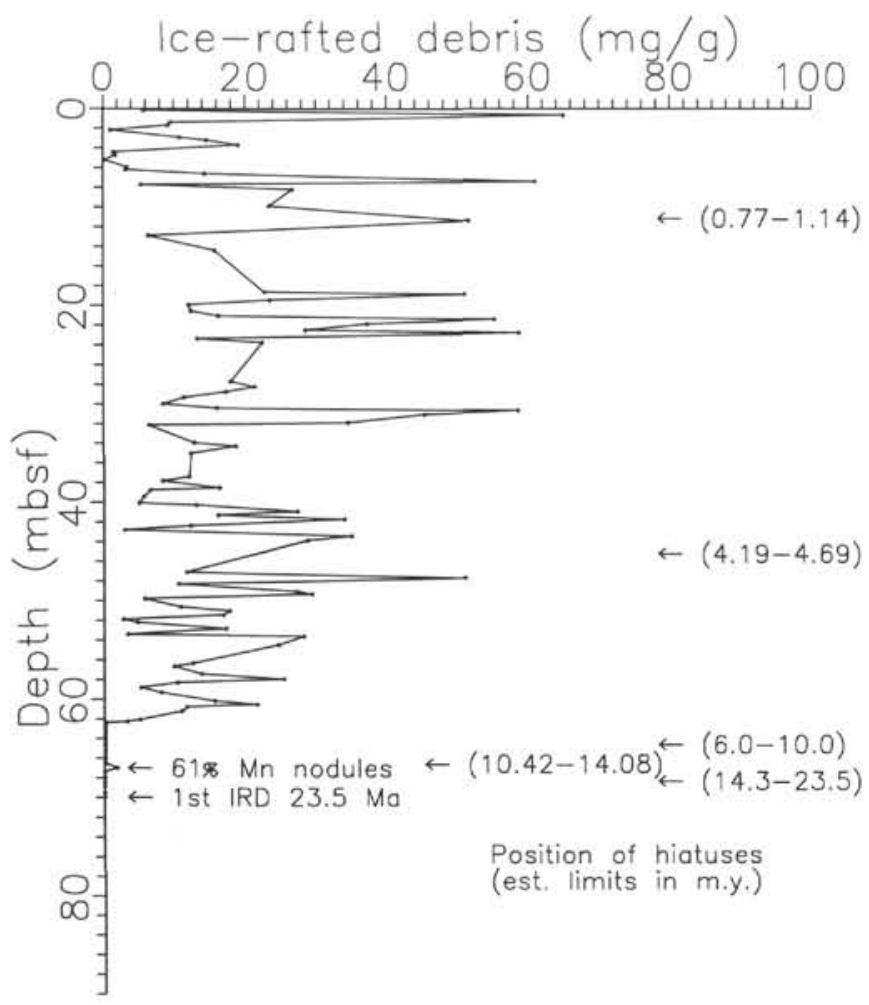

Figure 3. Coarse-grained ( $250 \mu \mathrm{m}$ to $2 \mathrm{~mm}$ ) ice-rafted debris, Site 699. Numbers in parentheses $=$ estimated limits of hiatuses.

in AMARs around 2.58-3.23 Ma and peaks younger than about $2.38 \mathrm{Ma}$ to be significant. The peak at about $2.38 \mathrm{Ma}$ can be traced from drill site to drill site (Allen and Warnke, this volume).

In contrast to Site 699 , Sites 701 and 704 have a highresolution record that allows first attempts to interpret AMARs of ice-rafted debris in terms of boundary conditions on Antarctica and allows interpretation of temperature changes when combined with other results from the cruise. The most outstanding feature of the record at both sites is the cluster of peaks from 2.46 to $1.79 \mathrm{Ma}$ (Figs. 5 and 6). We propose that this may be the marine equivalent of at least a part of the groups of tills collectively called the Sirius till (including the Sirius Formation-Prentice et al., 1986; see also Denton et al., 1986), but only if the Sirius till is confirmed as Pliocene in age. This postulated "Sirius till equivalent, marine" (STEM) can be identified at all our investigated drill sites. (The age of the equivalent group of terrestrial antarctic tills is given as <3 Ma; Webb et al., 1986. Unfortunately, it must be stressed that there is still a considerable divergence of opinion among researchers concerning the exact age of the Sirius till and that these differences at present seen irreconcilable.) The boundary conditions described by Denton et al. (1986) and Prentice et al. (1986) and the range of estimated sizes of these ice sheets ideally fit the modeling demands imposed by the high ice-rafted-debris flux rates in this time span. Opal percentages (Froelich et al., this volume) fit our assumption of temperatures higher than during much of Brunhes time but lower than in Gauss time. The postulated occurrence of woody plants on Antarctica in this interval (Prentice et al., 1986; Mercer, 1986) - if it can be confirmedalso fits this assumption. The higher temperatures (and higher

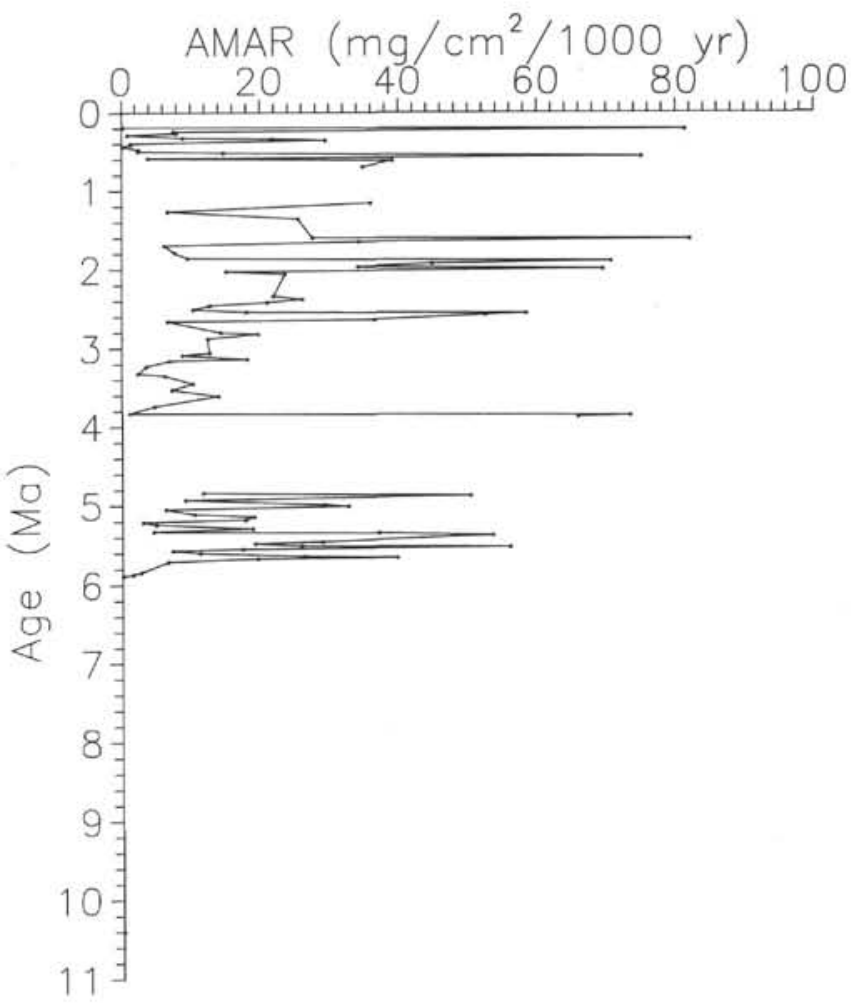

Figure 4. Apparent mass-accumulation rate (AMAR) of coarsegrained ice-rafted debris, Site 699.

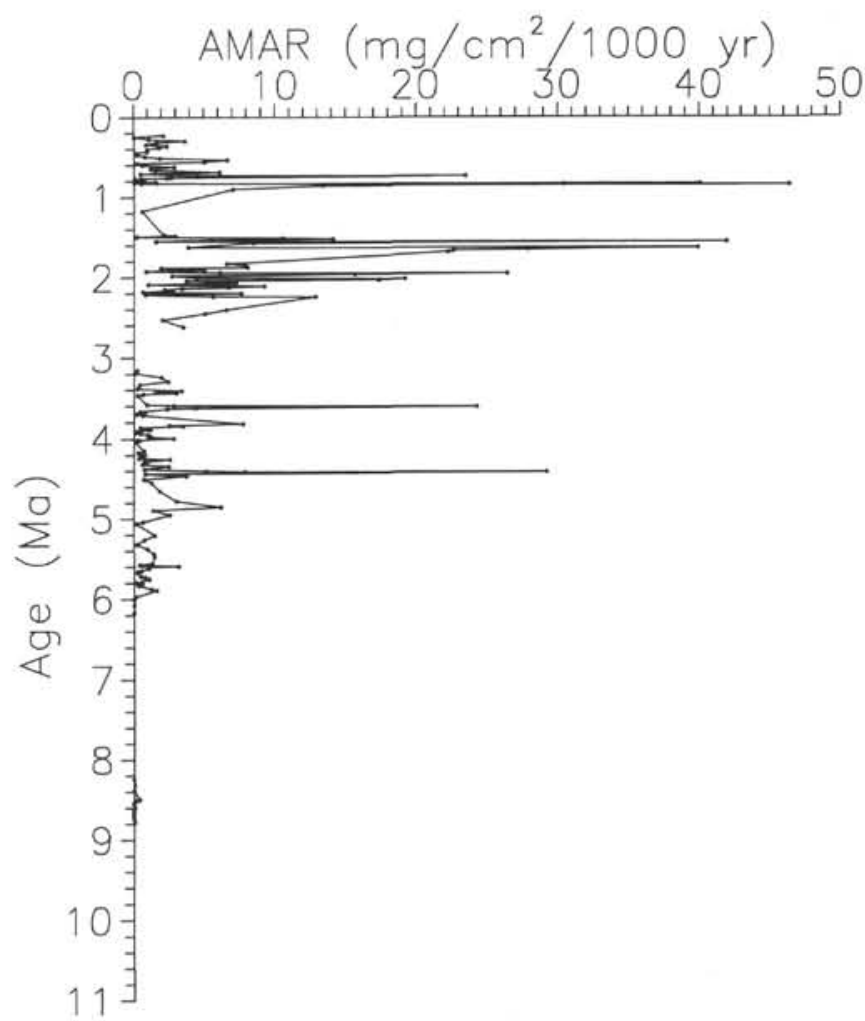

Figure 5. Apparent mass-accumulation rate (AMAR) of ice-rafted debris, Site 701. Explanation in text. 


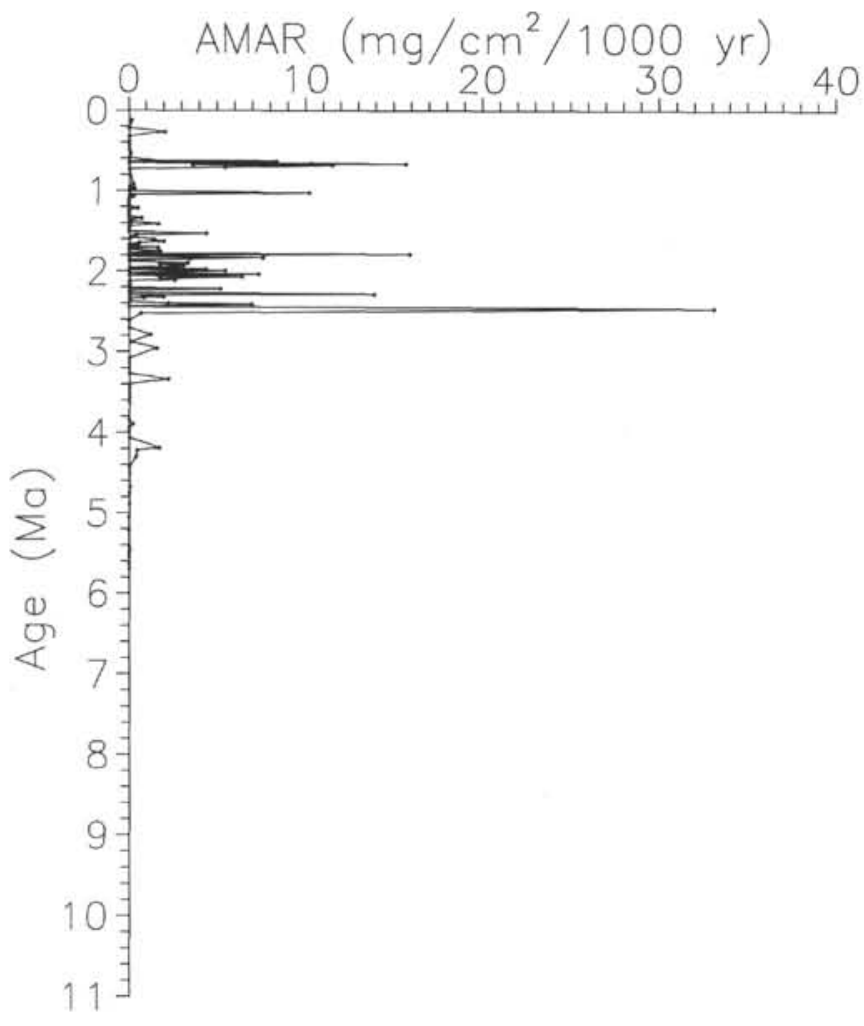

Figure 6. Apparent mass-accumulation rate (AMAR) of ice-rafted debris, Hole 704A. Note significant increase at about $2.5 \mathrm{Ma}$.

evaporation rates) explain, at least in part, the existence of large, wet-based continental glaciers, which were able to erode vigorously. It is interesting to compare this postulate with the results of modeling experiments by Oerlemans (1982), which suggest that at a sea-level temperature of $-5^{\circ} \mathrm{C}$ the ice thickness increases considerably in parts of East Antarctica. However, these findings must be considered with caution. Whatever the outcome of the "Sirius debate," the observed changes at $\sim 2.5 \mathrm{Ma}$ indicate a northward shift of the Polar Front Zone and significant glacial erosion on Antarctica.

We see a profound change in ice-rafted debris flux rates, at least at Site 704, at a depth of $100 \mathrm{~m}$ below seafloor (mbsf) (Fig. 7), at about $1.77 \mathrm{Ma}$ (Fig. 6). This change corresponds to a conspicuous change in planktonic $\delta^{18} \mathrm{O}$ values shown by Hodell and Ciesielski (this volume) and occurs precisely at a level of dramatic increase in the content of biogenic opal (Froelich et al., this volume). We think that all of these changes signify a drop in water temperatures of several degrees and a change to dry-based continental glaciers on much of Antarctica, as proposed by the authors quoted previously. Such a change in boundary conditions was proposed by Mercer (1968) and tentatively identified in the marine record by Warnke (1968). Determination of the exact timing of these changes, when applied to the marine record, was heretofore not possible because of the lack of drill holes with very high sedimentation rates at locations in the vicinity of the Antarctic Polar Front. As described previously, the assumption of a change to low temperatures at this time is corroborated by high opal percentages (see Froelich, this volume). These high percentages do not necessarily indicate high average annual primary production and, indeed, probably indicate the onset of more "modern" conditions, with low average annual production (see the preceding) and high opalaccumulation rates. The exact relationships between temper-

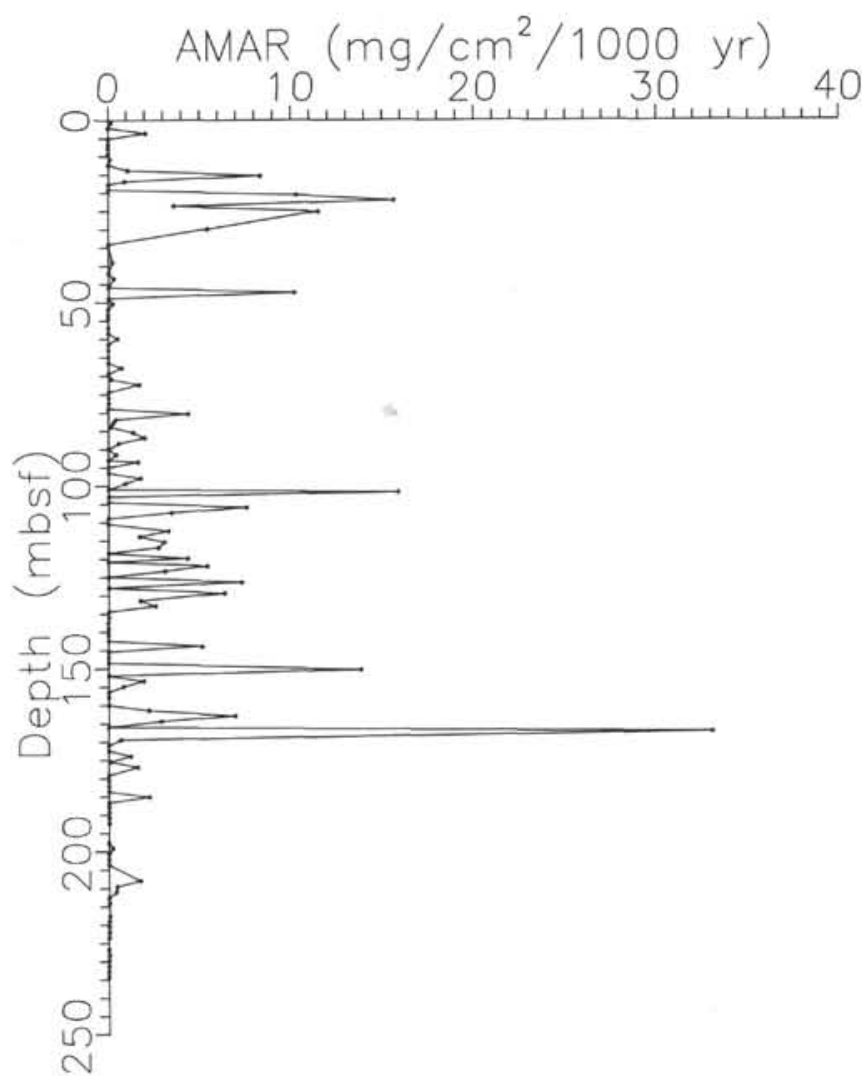

Figure 7. Apparent mass-accumulation rate (AMAR) of ice-rafted debris, Hole 704A, plotted vs. depth. Compare with opal percentage curve given in Froelich et al. (this volume). Note decrease in ice-rafted debris AMAR at exactly the same level where opal percentages increase substantially.

ature, productivity, opal content, opal-accumulation rates, and ice-rafted debris accumulation are focal points for future studies.

We have interpreted the ice-rafting episodes from $\sim 2.5$ to $1.77 \mathrm{Ma}$ as equivalent to a group of major continental glaciation episodes, following Denton et al. (1986), Webb et al. (1986), Prentice et al. (1986), and others in our interpretation. If this is so, then the interpretation of the oxygen isotope record given by Shackleton et al. (1984) must be revised in terms of major antarctic ice expansion as well as an attendant phase of Northern Hemisphere ice expansion (one of many) that happened to let ice rafting extend to DSDP Site 552 and to the drill sites in the Pacific studied by Rea and Schrader (1985). In any event, Northern Hemisphere glaciation started long before $2.37 \mathrm{Ma}$ (Warnke, 1982). The major "classical" glaciations, however, are confined to Brunhes time (see Jansen et al., 1988; Warnke and Hansen, 1977).

The peaks at about 3.8 and $4.4 \mathrm{Ma}$ (Site 701, see Fig. 5) may, at least in part, reflect large, wet-based glaciers and "overriding" episodes (Anderson, 1985). The same interpretation may apply to the peaks at about 1 and $0.7 \mathrm{Ma}$ (Site 704). In contrast, the younger peaks coincide with the classical Northern Hemisphere glaciations. During this time, the Hollin model of antarctic glaciation was operative, and lower sea levels, expansion of the antarctic ice sheets (Alley et al., 1986), and delivery of debris to the Southern Ocean were (nearly) in phase (Burckle and Cooke, 1983). These glaciations are also identified on the Vøring Plateau (Jansen et al., 1989) and off Spitsbergen (Warnke and Hansen, 1977; see also Warnke, 1982). 


\section{SUMMARY OF ICE-RAFTED DEBRIS INTERPRETATION}

One of the most encouraging results of ODP Leg 114 is the possible identification in the marine record of "Sirius conditions" on Antarctica, prevailing from about 2.46 to $1.79 \mathrm{Ma}$, if the age of at least some of the Sirius tills can be substantiated as Pliocene. Modern conditions, characterized by large polar ice sheets with little erosive power, are perhaps quite young $(0.6 \mathrm{Ma})$. The evidence from Leg 114 indicates that Antarctica underwent a long history-at least 23.5 m.y.- of intermittent glaciation, to be replaced in the last $0.6 \mathrm{Ma}$ or so by large, polar, "inefficient" ice sheets. In the Northern Hemisphere, glaciation started at least by $6 \mathrm{Ma}$, as evidenced by the Yakataga Formation in Alaska (Armentrout, 1983), and perhaps by the earliest glaciations on Iceland (Vilmundadottir, 1972) and off Spitsbergen (the glaciations "in the vicinity of the Miocene/Pliocene boundary" proposed by Warnke, 1982). These are perhaps all time equivalents.

"Modern" antarctic ice sheets have been used by some writers as analogs of Wisconsinan Northern Hemisphere ice sheets. However, there is no evidence in the North Atlantic marine record of late Pleistocene permanent ice shelves over the Norwegian-Greenland seas, that is, extensions of the large Eurasian ice sheet proposed by some writers (e.g., Grosswald, 1980) or a large arctic ice sheet (a term that includes ice shelves; see Hughes et al., 1977). The reader is referred to Talwani, Udintsev, et al. (1976) and Warnke (1982) for sediment descriptions and comparison with antarctic conditions. In the Southern Hemisphere, Sirius conditions (large, wet-based, vigorously eroding ice sheets) on Antarctica preceded the classical glaciations in the Northern Hemisphere. These classical glaciations in the Northern Hemisphere, on the other hand, resemble the large, efficient ice sheets of at least some of the pre-Pleistocene glaciations on Antarctica. "Modern" antarctic glaciations never developed in the Northern Hemisphere-yet.

\section{ACKNOWLEDGMENTS}

We wish to thank Lloyd Burckle, Bruce Molnia, George Plafker, and Sayed El-Sayed for thoughtful reviews of an earlier version of the manuscript. All errors of omission or commission, however, are our own. The senior author wishes to thank ODP for financial support to release him from his teaching duties at California State University, Hayward, and USSAC for post-cruise support. He particularly wishes to thank his shipmates on Leg 114 for innumerable, good-natured exchanges, challenges, discussions, and disputations on board the ship and after the cruise.

\section{REFERENCES}

Allanson, B. R., Hait, R. C., and Lutjeharms, J.R.E., 1981. Observations on the nutrients, chlorophyll and primary production of the Southern Ocean south of Africa. South Afr. J. Antarct. Res., 10:3-14.

Alley, R. B., Blankenship, D. D., Bentley, C. R., and Rooney, S. T., 1986. Deformation of till beneath ice stream B, West Antarctica. Nature, 322:57-59.

Anderson, D. M., 1985. Pliocene paleoceanography of the Southern Ocean and the development of the West Antarctic Ice Sheet [M.S. thesis]. San Jose State Univ., San Jose, CA.

Anderson, J. B., Brake, C., Domack, E., Myers, N., and Wright, R., 1983. Development of a polar glacial-marine sedimentation model from antarctic Quaternary deposits and glaciological information. In Molnia, B. F. (Ed.), Glacial-Marine Sedimentation: New York (Plenum Press), 233-264.

Anderson, J. B., Domack, E. W., and Kurtz, D. D., 1980. Observation of sediment-laden icebergs in Antarctic waters: implications to glacial erosion and transport. J. Glaciol., 25:387-396.
Armentrout, J. M., 1983. Glacial lithofacies of the Neogene Yakataga Formation, Robinson Mountains, southern Alaska Coast Range, Alaska. In Molnia, B. F. (Ed.), Glacial-Marine Sedimentation: New York (Plenum Press), 629-665.

Barnes, P. W., and Lien, R., 1988. Icebergs rework shelf sediments to $500 \mathrm{~m}$ off Antarctica. Geology, 16:1130-1133.

Bentley, C. R., 1987. Antarctic ice streams: a review. J. Geophys. Res., 92:8843-8858.

Birkenmajer, K., 1986. Onset and course of Tertiary glaciation, Antarctic Peninsula sector, West Antarctica. Second Int. Conf. Paleocean. Abstracts (unnumbered). (Abstract)

Blankenship, D. D., Bentley, C. R., Rooney, S. T., and Alley, R. B., 1986. Seismic measurements reveal a saturated porous layer beneath an active Antarctic ice stream. Nature, 322:54-57.

Bralower, T. J., and Thierstein, H. R., 1984. Low productivity and slow deep-water circulation in mid-Cretaceous oceans. Geology, 12:614-618.

Brewster, N. A., 1980. Cenozoic biogenic silica sedimentation in the Antarctic Ocean, based on two Deep Sea Drilling Project sites. Geol. Soc. Am. Bull., 91:337-349.

Burckle, L. H., and Cirilli, J., 1987. Origin of diatom ooze belt in the Southern Ocean: implications for late Quaternary paleoceanography. Micropaleontology, 33:82-86.

Burckle, L. H., and Cooke, D. W., 1983. Late Pleistocene Eucampia antarctica abundance stratigraphy in the Atlantic sector of the Southern Ocean. Micropaleontology, 29:6-10.

Burckle, L. H., Jacobs, S. S., and McLaughlin, R. B., 1987. Late spring diatom distribution between New Zealand and the Ross Sea Ice Shelf: hydrographic and sediment correlations. Micropaleontology, 33:74-81.

Burckle, L. H., Robinson, D., and Cooke, D. W., 1982. Re-appraisal of sea-ice distribution in Atlantic and Pacific sectors of the Southern Ocean at 18,000 yrs BP. Nature, 299:435-437.

Ciesielski, P. F., Kristoffersen, Y., et al., 1988. Proc. ODP, Init. Repts., 114: College Station, TX (Ocean Drilling Program).

Ciesielski, P. F., and Weaver, F. M., 1983. Neogene and Quaternary paleoenvironmental history of Deep Sea Drilling Project Leg 71 sediments, southwest Atlantic Ocean. In Ludwig, W. J., Krasheninnikov, V. A., et al., Init. Repts. DSDP, 71 (Pt. 1): Washington (U.S. Govt. Printing Office), 461-477.

Cooke, D. W., and Hays, J. D., 1982. Estimates of Antarctic Ocean seasonal sea-ice cover during glacial intervals. In Craddock, C. (Ed.), Antarctic Geoscience: Madison (Univ. Wisconsin Press): 1017-1025.

DeMaster, D. J., 1981. The supply and accumulation of silica in the marine environment: Geochim. Cosmochim. Acta, 45:17151732.

DeMaster, D. J., Nelson, T. M., Nittrouer, C. A., and Harden, S. L., 1987. Biogenic silica and organic carbon accumulation in modern Bransfield Strait sediments. Antarct. J. U.S., 22:108-110.

Denton, G. H., Andersen, B. G., and Conway, H. W., 1986. Late Quaternary surface fluctuations of Beardmore Glacier, Antarctica. Antarct. J. U.S., 21:90-92.

El-Sayed, S. Z., 1971. Observations on phytoplankton bloom in the Weddell Sea. In Llano, G. A., and Wallen, I. E. (Eds.), Biology of the Antarctic Seas II. Antarctic Res. Ser., 5:87-106.

1987. Biological productivity of antarctic waters: present paradoxes and emerging paradigms. In El-Sayed, S. Z., and Tomo, A. P. (Eds.), Biological Investigations of Marine Antarctic Systems and Stocks (Biomass): Antarctic Aquatic Biology (vol. 7): Cambridge (SCAR, Scott Polar Research Inst.), 1-21.

El-Sayed, S. Z., and Taguchi, S., 1981. Primary production and standing crop of phytoplankton along the ice-edge in the Weddell Sea. Deep-Sea Res., Part A, 28:1017-1032.

El-Sayed, S. Z., and Turner, J. T., 1977. Productivity of the antarctic and tropical/subtropical regions: a comparative study. In Dunbar, M. J. (Ed.), Polar Oceans: Calgary (Arctic Inst. North America), $463-501$

El-Sayed, S. Z., and Weber, L. H., 1982. Spatial and temporal variations in phytoplankton biomass and primary productivity in the southwest Atlantic and the Scotia Sea. Polar Biol., 1:83-90.

Emerson, S., and Hedges, J. I., 1988. Processes controlling the organic carbon content of open ocean sediments. Paleoceanography, 3:621-634. 
Fenner, J., Schrader, H. J., and Wienigk, H., 1976. Diatom phytoplankton studies in the southern Pacific Ocean, composition and correlation to the Antarctic convergence and its paleoecological significance. In Simpson, E.S.W., Schlich, R., et al., Init. Repts. DSDP, 35: Washington (U.S. Govt. Printing Office), 757-813.

Gersonde, R., and Wefer, G., 1987. Sedimentation of biogenic siliceous articles in antarctic waters from the Atlantic sector. Mar. Micropaleontol., 11:311-332.

Goodell, H. G., and Watkins, N. D., 1968. Paleomagnetic stratigraphy of the Southern Ocean: $20^{\circ} \mathrm{W}$ to $160^{\circ} \mathrm{E}$ longitude. Deep-Sea Res., Part A, 15:89-112.

Grosswald, M. G., 1980. Late Weichselian Ice Sheet of northern Eurasia. Quat. Res., 13:1-32.

Hay, W. W., 1988. Paleoceanography: a review for the GSA Centennial. Geol. Soc. Am. Bull., 100:1934-1956.

Hayes, D. E., and Frakes, L. A., 1975. General synthesis, Deep Sea Drilling Project, Leg 28. In Hayes, D. E., Frakes, L. A., et al., Init. Repts. DSDP, 28: Washington (Govt. Printing Office), 919924.

Holm-Hansen, O., El-Sayed, S. Z., Francheschini, G., and Cuhel, K., 1977. Primary production and the factors controlling phytoplankton growth in the antarctic seas. In Llano, G. A. (Ed.), Adaptations within Antarctic Ecosystems: Washington (Smithsonian Institution), 11-50.

Hughes, T. C., Denton, G. H., and Grosswald, M. G., 1977. Was there a late Wurm Arctic Ice Sheet? Nature, 266:596-602.

Hurd, D. C., 1973. Interactions of biogenic opal, sediment and seawater in the central equatorial Pacific. Geochim. Cosmochim. Acta, 37:2257-2282.

Jansen, E., Bleil, U., Henrich, R., Kringstad, L., and Slettemark, B., 1988. Paleoenvironmental changes in the Norwegian Sea and the northeast Atlantic during the last 2.8 m.y.: Deep Sea Drilling Project/Ocean Drilling Program Sites 610, 642, 643 and 644. Paleoceanography, 3:563-581.

Kellogg, T. B., and Kellogg, D. E., 1988. Antarctic cryogenic sediments: biotic and inorganic facies of ice shelf and marinebased ice sheet environments. Palaeogeogr., Palaeoclimatol., Palaeoecol., 67:51-74.

Kennett, J. P., Barron, J., and the Ocean Drilling Program Legs 113 and 119 Scientific Parties, 1988. Antarctic Ocean drilling: continental glacial development and the evolution of water masses and biota. EOS, Trans. Am. Geophys. Union, 69:1047-1048. (Abstract)

Leckie, R. M., and Webb, P. N., 1983. Late Oligocene-early Miocene glacial record of the Ross Sea, Antarctica: evidence from DSDP Site 270. Geology, 11:578-582.

Ledford-Hoffman, P. A., DeMaster, D. J., and Nittrouer, C. A., 1986. Biogenic-silica accumulation in the Ross Sea and the importance of antarctic continental-shelf deposits in the marine silica budget. Geochim. Cosmochim. Acta, 50:2099-2110.

LeMasurier, W. E., and Rex, D. C., 1982. Volcanic record of Cenozoic glacial history in Marie Byrd Land and Western Ellsworth Land: revised chronology and evaluation of tectonic factors. In Craddock, C. (Ed.), Antarctic Geoscience: Madison (Univ. Wisconsin Press), 725-734.

Matthews, R. K., and Poore, R. Z., 1980. Tertiary ${ }^{18} \mathrm{O}$ record and glacio-eustatic sea level fluctuations. Geology, 8:500-514.

Mercer, J. H., 1968. Glacial geology of the Reedy Glacier area, Antarctica. Geol. Soc. Am. Bull., 79:471-486.

1986. Southernmost Chile: a modern analog of the southern shores of the Ross Embayment during Pliocene warm intervals. Antarct. J. U.S., 21:103-105.

Miller, K. G., Fairbanks, R. G., and Mountain, G. S., 1987. Tertiary oxygen isotope synthesis, sea level history, and continental margin erosion. Paleoceanography, 2:1-19.

Molnia, B. F., 1983. Distal glacial-marine sedimentation: abundance, composition, and distribution of North Atlantic Ocean Pleistocene ice-rafted sediment. In Molnia, B. F. (Ed.), Glacial-Marine Sedimentation: New York (Plenum Press), 593-625.

Odell, N. E., 1952. Antarctic glaciers and glaciology. In Simpson, F. A. (Ed.), The Antarctic Today: Wellington (New Zealand Antarct. Soc.), 25-55.

Oerlemans, J., 1982. A model of the Antarctic Ice Sheet. Nature, 297:550-553.
Ovenshine, A. T., 1970. Observations of iceberg rafting in Glacier Bay, Alaska, and the identification of ice-rafted deposits. Geol. Soc. Am. Bull., 81:891-894.

Philippi, E., 1912. Die Grundproben der deutschen Sudpolar-Expedition 1901-1903. In von Drygalski, von E. (Ed.), Deutsche Südpolar-Expedition 1901-1903 (vol. 2): Berlin (G. Reimer), 415-616.

Prentice, M. L., Denton, G. H., Lowell, T. V., Conway, H. C., and Heusser, L. E., 1986. Pre-late Quaternary glaciation of the Beardmore Glacier region, Antarctica. Antarct. J. U.S., 21:95-98.

Rea, D. K., and Schrader, H., 1985. Late Pliocene onset of glaciation: ice rafting and diatom stratigraphy of North Pacific DSDP cores. Palaeogeogr., Palaeoclimat., Palaeoecol., 49:313-325.

Sakshaug, E., and Holm-Hansen, O., 1986. Photoadaptation in antarctic phytoplankton: variations in growth rate, chemical composition, and $P$ vs. $I$ curves. J. Plankton Res., 8:459-473.

Schott, W., 1939. Deep-sea sediments of the Indian Ocean. In Trask, P. (Ed.), Recent Marine Sediments: A Symposium: Tulsa, OK (AAPG), 396-408.

Shackleton, N. J., Backman, J., Zimmerman, H., Kent, D. V., Hall, M. A., Roberts, D. F., Schnitker, D., Baldauf, J. G., Desprairies, A., Homrighausen, R., Huddlestun, P., Keene, J. B., Kaltenback, A. J., Krumsiek, K.A.O., Morton, A. C., Murray, J. W., and Westberg-Smith, J., 1984. Oxygen isotope calibration of the onset of ice-rafting and history of glaciation in the North Atlantic region. Nature, 307:620-623.

Shemesh, A., Burckle, L. H., and Froelich, P. N., in press. Dissolution and preservation of antarctic diatoms and the effect on sediment thanatocoenoses. Quat. Res.

Stein, R., 1986. Surface-water paleo-productivity as inferred from sediments deposited in oxic and anoxic deep-water environments of the Mesozoic Atlantic Ocean. Mitt. Geol.-Palaeontol. Inst. Univ. Hamburg, 60:55-70.

Stein, R., Rullkötter, J., and Welte, D. H., 1986. Accumulation of organic-carbon-rich sediments in the late Jurassic and Cretaceous Atlantic Ocean-a synthesis. Chem. Geol., 56:1-32.

Talwani, M., Udintsev, G., et al., 1976. Init. Repts. DSDP, 38: Washington (U.S. Govt. Printing Office).

Tilzer, M. M., Elbracher, M., Gieskes, W. W., and Beese, B., 1986. Light-temperature interactions in the control of photosynthesis of antarctic phytoplankton. Polar Biol., 5:105-111.

Tucholke, B. E., Hollister, C. D., Weaver, F. M., and Vennum, W. R., 1976. Continental rise and abyssal plains sedimentation in the southeast Pacific Basin, Leg 35 Deep Sea Drilling Project. In Hollister, C. D., Craddock, C., et al., Init. Repts. DSDP, 35: Washington (U.S. Govt. Printing Office), 359-400.

Vilmundadottir, E. G., 1972. Report on geological investigations of Jokulsa in Fljotsdal Valley, summer 1970: Reykjavik (Natl. Energy Authority-Orkustofnun).

Walsh, J. J., 1969. Vertical distribution of antarctic phytoplankton standing crops in the Southern Ocean. Limnol. Oceanogr., 14:8694.

Warnke, D. A., 1968. Comments on a paper by H. G. Goodell and N. D. Watkins, "The paleomagnetic stratigraphy of the Southern Ocean: $20^{\circ}$ West to $160^{\circ}$ East longitude." Deep-Sea Res., Part A, 15:723-725.

1970. Glacial erosion, ice rafting, and glacial-marine sediments: Antarctica and the Southern Ocean. Am. J. Sci., 269:276294.

1982. Pre-middle Pliocene sediments of glacial and periglacial origin in the Norwegian-Greenland seas: results of D.S.D.P. Leg 38. Earth Evol. Sci., 2:69-78.

Warnke, D. A., and Hansen, M. E., 1977. Sediments of glacial origin in the area of operations of D.S.D.P. Leg 38 (NorwegianGreenland Seas): preliminary results from Sites 336 and 344. Naturforsch. Ges. Freiburg/Br. (Pfannenstiel Gedenkband), 67:371-392.

Warnke, D. A., and Pavletich, J. P., 1988. A question of hiatuses. Geol. Soc. Am. Abstr. Programs, 27:A175. (Abstract)

Warnke, D. A., and Richter, J. J., 1970. Sedimentary petrography of till from a floating iceberg in Arthur Harbor, Antarctic Peninsula. Rev. Geogr. Phys. Geol. Dyn., 12:441-448.

Warnke, D. A., Richter, J., and Oppenheimer, C., 1973. Characteristics of the nearshore environment off the south coast of Anvess Island, Antarctic Peninsula. Limnol. Oceanogr., 18:131-142. 
Webb, P. W., Harwood, D. M., McKelvey, B. C., Mabin, M.C.G., and Mercer, J. H., 1986. Late Cenozoic tectonics and glacial history of the Transantarctic Mountains. Antarct. J. U.S., 21:99100.

Wise, S. W., Gombos, A. M., and Muza, J. P., 1985. Cenozoic evolution of polar water masses, southwest Atlantic Ocean. In Hsü, K. J., and Weissert, H. J. (Eds.), South Atlantic Paleoceanography: Cambridge (Cambridge Univ. Press), 283-324.
Yamaguchi, Y., and Shibata, Y., 1982. Standing stock and distribution of phytoplankton chlorophyll in the Southern Ocean south of Australia. Trans. Tokyo Univ. Fish., 5:111-128.

Date of initial receipt: 21 April 1989 Date of acceptance: 25 January 1990 Ms 114B-117 